\title{
Surface-attached cells, biofilms and biocide susceptibility: Implications for hospital cleaning and disinfection
}

\author{
Authors: J.A. Otter, K. Vickery, J.T. Walker, E. \\ deLancey Pulcini, P. Stoodley, S.D. Goldenberg, J.A.G. \\ Salkeld, J. Chewins, S. Yezli, \& J.D. Edgeworth
}

NOTICE: this is the author's version of a work that was accepted for publication in Journal of Hospital Infection. Changes resulting from the publishing process, such as peer review, editing, corrections, structural formatting, and other quality control mechanisms may not be reflected in this document. Changes may have been made to this work since it was submitted for publication. A definitive version was subsequently published in Journal of Hospital Infection, VOL\# 89, ISSUE\# 1, (January 2015) DOI\# 10.1016/j.jhin.2014.09.008

Otter JA, Vickery K, Walker JT, de Lancey Pulcini E, Stoodley P, Goldenberg SD, Salkeld JA, Chewins J, Yezli S, Edgeworth JD, "Surface-attached cells, biofilms and biocide susceptibility: Implications for hospital cleaning and disinfection," Journal of Hospital Infection. January 2015 89(1):16-27. 


\title{
Surface-attached cells, biofilms and biocide susceptibility: implications for hospital cleaning and disinfection
}

\author{
J.A. Otter ${ }^{\mathrm{a}, \mathrm{b}, *}, \mathrm{~K}$. Vickery ${ }^{\mathrm{c}}$, J.T. Walker $^{\mathrm{d}}$, E. deLancey Pulcini ${ }^{\mathrm{e}}$, P. Stoodley ${ }^{\mathrm{f}, \mathrm{g}}$, \\ S.D. Goldenberg ${ }^{\text {a }}$, J.A.G. Salkeld ${ }^{b}$, J. Chewins ${ }^{b}$, S. Yezli ${ }^{b}$, J.D. Edgeworth ${ }^{a}$ \\ a Centre for Clinical Infection and Diagnostics Research, Department of Infectious Diseases, King's College London and Guy's and \\ St. Thomas' NHS Foundation Trust, London, UK \\ ${ }^{\mathrm{b}}$ Bioquell (UK) Ltd., Andover, UK \\ 'Australian School of Advanced Medicine, Macquarie University, Nth Ryde, Australia \\ d Public Health England MSD, Porton Down, Salisbury, UK \\ e Center for Biofilm Engineering, Montana State University, Bozeman, MT, USA \\ ${ }^{f}$ Departments of Microbial Infection and Immunity and Orthopedics, Ohio State University, Columbus, OH, USA \\ ${ }^{\mathrm{g}}$ National Centre for Advanced Tribology, University of Southampton, Southampton, UK
}

\section{Summary}

Microbes tend to attach to available surfaces and readily form biofilms, which is prob-lematic in healthcare settings. Biofilms are traditionally associated with wet or damp surfaces such as indwelling medical devices and tubing on medical equipment. However, microbes can survive for extended periods in a desiccated state on dry hospital surfaces, and biofilms have recently been discovered on dry hospital surfaces. Microbes attached to surfaces and in biofilms are less susceptible to biocides, antibiotics and physical stress. Thus, surface attachment and/or biofilm formation may explain how vegetative bacteria can survive on surfaces for weeks to months (or more), interfere with attempts to recover microbes through environmental sampling, and provide a mixed bacterial population for the horizontal transfer of resistance genes. The capacity of existing detergent formula-tions and disinfectants to disrupt biofilms may have an important and previously unrec-ognized role in determining their effectiveness in the field, which should be reflected in testing standards. There is a need for further research to elucidate the nature and physiology of microbes on dry hospital surfaces, specifically the prevalence and compo-sition of biofilms. This will inform new approaches to hospital cleaning and disinfection, including novel surfaces that reduce microbial attachment and improve microbial detachment, and methods to augment the activity of biocides against surface-attached microbes such as bacteriophages and antimicrobial peptides. Future strategies to address environmental contamination on hospital surfaces should consider the presence of microbes attached to surfaces, including biofilms. 


\section{Introduction}

Microbes tend to attach to available surfaces and form biofilms readily. ${ }^{1-3}$ Biofilms are problematic in healthcare settings, where they are thought to be involved in $65 \%$ of nosocomial infections, and are usually reported in relation to indwelling medical devices and prostheses, water lines and tubing on endoscopes, and on wounds. ${ }^{1-3}$ In these settings, biofilm persistence can be prolonged, periodically 'sloughing off' and releasing planktonic bacteria that may act as a source of infection. Biofilms are a common problem on liquid-hard surface interfaces, and in areas of a hospital that are usually wet or damp, such as taps and sink drains. ${ }^{4}$ The recent problems caused by Pseudomonas aeruginosa in water supplied to intensive care units, which resulted in changes to UK national guidance, illustrates this problem. ${ }^{4}$

A biofilm is a community of micro-organisms attached to a substrate producing extracellular polymeric substances (EPS) and exhibiting an altered phenotype compared with corresponding planktonic cells, especially regarding growth, gene transcription, protein production and intercellular interaction. ${ }^{1-3,5,6}$ Biofilms comprising various micro-organisms, including bacteria, viruses, fungi and other micro-organisms, can form on almost any biological or inanimate surface, and have been identified in various industrial and clinical settings. ${ }^{1,7}$ Not all microbes attached to surfaces meet the definition of a biofilm, and the transition from a planktonic culture through surface attachment to an established biofilm is likely to be a continuum rather than a stepwise process (Figure 1). ${ }^{1-3}$

Microbes including bacterial spores, vegetative bacteria, fungi and viruses can also survive on dry surfaces for extended periods. ${ }^{8-10}$ Contaminated environmental surfaces are an increasingly recognized reservoir in the transmission of certain healthcare-associated pathogens. ${ }^{11-13}$ Whilst this extended survival is not surprising for the metabolically inert bacterial endospores, survival of some vegetative bacteria that is measured in years rather than days challenges our understanding of bacterial physiology. ${ }^{10,14}$ The structural and physiological state of microbes dried on to hospital surfaces has not been studied in detail, but it seems likely that bacteria attach to surfaces to some degree, and may form biofilms. Indeed, a recent study from Australia by Vickery et al. ${ }^{15}$ 'destructively sampled' (i.e. cut the materials out of the hospital environment and undertook laboratory analysis) several hospital surfaces after cleaning and bleach disinfection. Scanning electron microscopy was used to examine the surfaces for biofilms, which were identified on five of six surfaces. Furthermore, viable meticillin-resistant Staphylococcus aureus (MRSA) was identified in the biofilm on three of the surfaces.

This article will review in-vitro studies that explore the structure, physiology and biocide susceptibility of microbes dried on to hard surfaces in the context of surface attachment and biofilm establishment, and discuss the potential implications for hospital cleaning and disinfection. ${ }^{16}$

\section{Search strategy}

Pubmed was searched with no date restrictions using the search terms 'biofilm and biocide', 'biofilm and reduced susceptibility', 'biofilm and [MRSA, VRE, C. difficile, Acinetobacter, E. coli, Pseudomonas]' and 'susceptibility planktonic biofilm biocide' (see Figure 1). The reference lists of articles identified via the Pubmed searches were hand searched to identify other relevant literature.

\section{Resistance and reduced susceptibility}

Biofilms constitute a protected mode of growth, allowing bacteria to survive in hostile environments and conferring

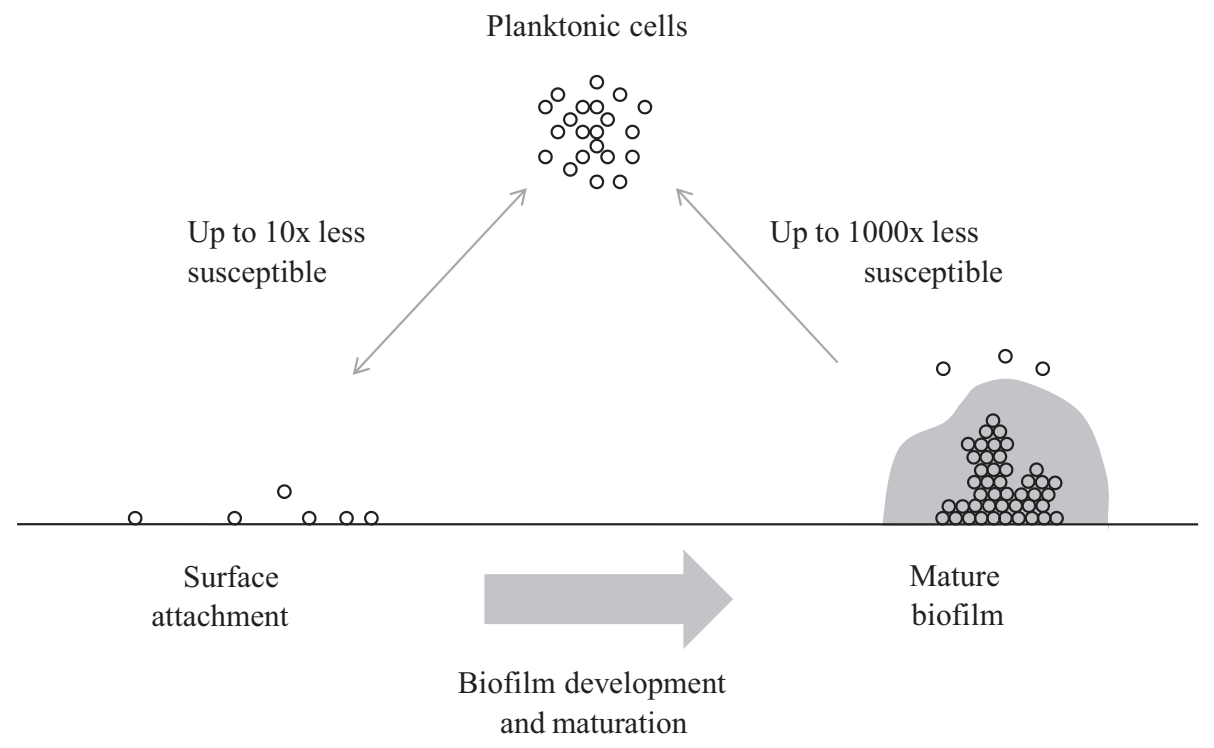

Figure 1. Schematic of surface attachment, biofilm formation and biocide susceptibility. This illustrates bacterial attachment to surfaces, development and maturation of biofilms, and implications for microbial susceptibility. The grey shading around the mature biofilms illustrates EPS. The biofilm development and maturation process is a complex step-wise process, simplified here as a single step. ${ }^{2,3}$ Whilst $^{2}$ the reduced biocide susceptibility associated with surface attachment and biofilms will be determined by a number of factors, not least the biocide, microbe and testing conditions, bacteria in mature biofilms are consistently less susceptible than biofilms attached to surfaces, often by several orders of magnitude. ${ }^{18-20}$ 
reduced susceptibility to dehydration, phagocytosis, metal toxicity, acid exposure, antibiotics and biocides. ${ }^{1,7,17}$ Microbes attached to surfaces that have not formed an established biofilm appear to represent an intermediate step, with reduced susceptibility to biocides compared with planktonic cells, but increased susceptibility relative to biofilms (Figure 1). ${ }^{18-20}$

\section{Mechanisms of reduced susceptibility}

Causes of reduced susceptibility to antimicrobial agents in biofilms are multi-factorial, including reduced penetration (particularly due to changes in cell density and the production of EPS), slow growth (and subsequent reduced metabolism of antimicrobial agents), modulation of the stress response and other metabolic processes, and changes in quorum sensing. ${ }^{5,21-23}$ It seems likely that these mechanisms also explain reduced biocide susceptibility in surface-attached cells that have not yet formed biofilms.

\section{Biocide susceptibility}

Many studies have evaluated the impact of established biofilms on biocide susceptibility, and fewer studies have evaluated the susceptibility of surface-attached cells that have not yet formed established biofilms (Figure 1). Table I summarizes studies that have investigated organisms and biocides relevant to disinfection in healthcare settings that include data comparing susceptibility in planktonic culture with surfaceattached cells and/or biofilms. Studies have evaluated a range of organisms (both alone and in combination), various suspending media, and several methods of attaching cells to surfaces and producing biofilms on different substrates; all of these factors are likely to influence biocide susceptibility. One important factor is the maturation of the microbes tested, which ranges from cells attached to surfaces for hours to samples extracted from continuously fed biofilm reactors that are weeks old. ${ }^{24,25}$ Furthermore, few studies have controlled for cell density in attached cells or biofilms compared with planktonic culture. ${ }^{26}$ Thus, although several studies have suggested that cell density alone does not explain the reduced susceptibility of biofilms to biocides, it is difficult to be certain of the impact of the biofilm phenotype independent of cell density in many studies. ${ }^{20,27-29}$ A number of different approaches have been taken to quantify growth, including both direct microbial culture and indirect measures, such as live/ dead viability assays. ${ }^{20,30-32}$ Finally, different approaches to compare susceptibility in planktonic culture and biofilms have included measuring the amount of biocide required to inhibit growth [minimum inhibitory concentration (MIC)] or kill cells

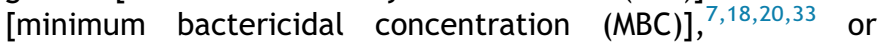
measuring the survival time at a given concentration of biocide; ${ }^{20,32,34,35}$ this makes comparison of studies difficult.

Notwithstanding difficulties in comparing studies, the phase of the surface-attached cells influences biocide susceptibility. In general, bacteria in planktonic culture are more susceptible than attached cells, which are, in turn, more susceptible than established biofilms (Figure 1). ${ }^{18-20}$ Meanwhile, detached biofilm cells revert to the susceptible phenotypic state. ${ }^{19,36,37}$ Similarly, growth phase affects biocide susceptibility of planktonic culture. ${ }^{38-40}$ Reduced susceptibility in surfaceattached cells ranges widely from two-fold to $>1000$ fold. $^{26,41}$ For example, clinical isolates of MRSA and $P$. aeruginosa were grown as biofilms on discs of common materials in the hospital environment, and treated with three commonly used hospital biocides: benzalkonium chloride $(1 \%$ $\mathrm{w} / \mathrm{v})$, chlorhexidine gluconate $(4 \% \mathrm{w} / \mathrm{v})$ and triclosan $(1 \% \mathrm{w} /$ v). ${ }^{7}$ The $M B C s$ of all biocides for planktonic cultures of both organisms were considerably less than the concentrations recommended for use by the manufacturer. However, when isolates were grown as biofilms, the biocides were ineffective at killing bacteria at the concentrations recommended for use. The MBCs of all three biocides were found to be 10-1000-fold higher than the same isolates grown in planktonic culture for MRSA and $P$. aeruginosa. Following biocide treatment, up to $11 \%$ of cells in MRSA biofilms survived, and up to $80 \%$ of cells in $P$. aeruginosa biofilms survived. Another study evaluated the susceptibility of four Candida spp. and two Escherichia coli strains to sodium hypochlorite, ethanol, hydrogen peroxide and iodine. ${ }^{20}$ Strains were tested in planktonic culture, as attached cells and as biofilms in microtitre plates. Whilst susceptibility varied by organism and biocide, biofilms were less susceptible than attached cells, which were less susceptible than planktonic cells. MICs for biofilms were up to $>10$-fold higher for 5min and 24-h exposures compared with planktonic cells. These studies suggest that although biocides may be effective against planktonic populations of bacteria, some biocides currently used in hospitals may be ineffective against nosocomial pathogens when attached to surfaces or in biofilms, and thus fail to control this reservoir for hospital-acquired infection.

However, whilst surface-attached microbes and biofilms are generally less susceptible to biocides than bacteria in planktonic culture, the degree of reduced susceptibility is not always this stark. For example, a study reported no difference between planktonic culture and biofilms of Klebsiella pneumoniae exposed to sodium hypochlorite and monochloramine. ${ }^{42}$ Other studies have not identified reduced susceptibility for all biocides or organisms tested. ${ }^{20,24,43,44}$ It is difficult to determine the relative importance of organism, biocide and testing conditions in these studies that found little or no reduced biocide susceptibility associated with biofilms.

The composition of the biofilm also influences susceptibility. For example, high-nutrient, high-density biofilms are less susceptible to biocides than low-nutrient, low-density biofilms. ${ }^{18,31,45}$ This seems particularly important in the context of biofilms that may be present on hospital surfaces, which are likely to be low-nutrient, low-density biofilms in most cases. However, gross contamination with body fluids could provide an environment in which high-nutrient, high-density biofilms could form on hospital surfaces. Indeed, three-quarters of the biofilms reported by Vickery et al. had very thick EPS despite having a low density of microbes in most cases, perhaps in response to desiccation. ${ }^{15,46,47}$

The microbial ecology of the biofilm is another factor influencing susceptibility. Biofilms composed of multiple species are less susceptible than single-species biofilms, although this is not always the case with the corresponding planktonic cultures. ${ }^{19,36,37,48}$

Some biocides are more effective than others at inactivating bacteria in biofilms, although conflicting data have been reported, which may be explained by differences in experimental conditions. ${ }^{20,24,35,49,50}$ In one study, susceptibility varied by phase, organism and biocide. ${ }^{20}$ In another study, the oxidizing agents sodium hypochlorite and peroxygens were more effective than a range of other chemicals (including alcohols, biguanides, halogens, phenols and quaternary ammonium compounds) for inactivating $P$. aeruginosa and $S$. aureus biofilms. $^{35}$ In other studies, sodium hypochlorite was more 
Table I

Biocide susceptibility of planktonic vs surface-attached and/or biofilm mode

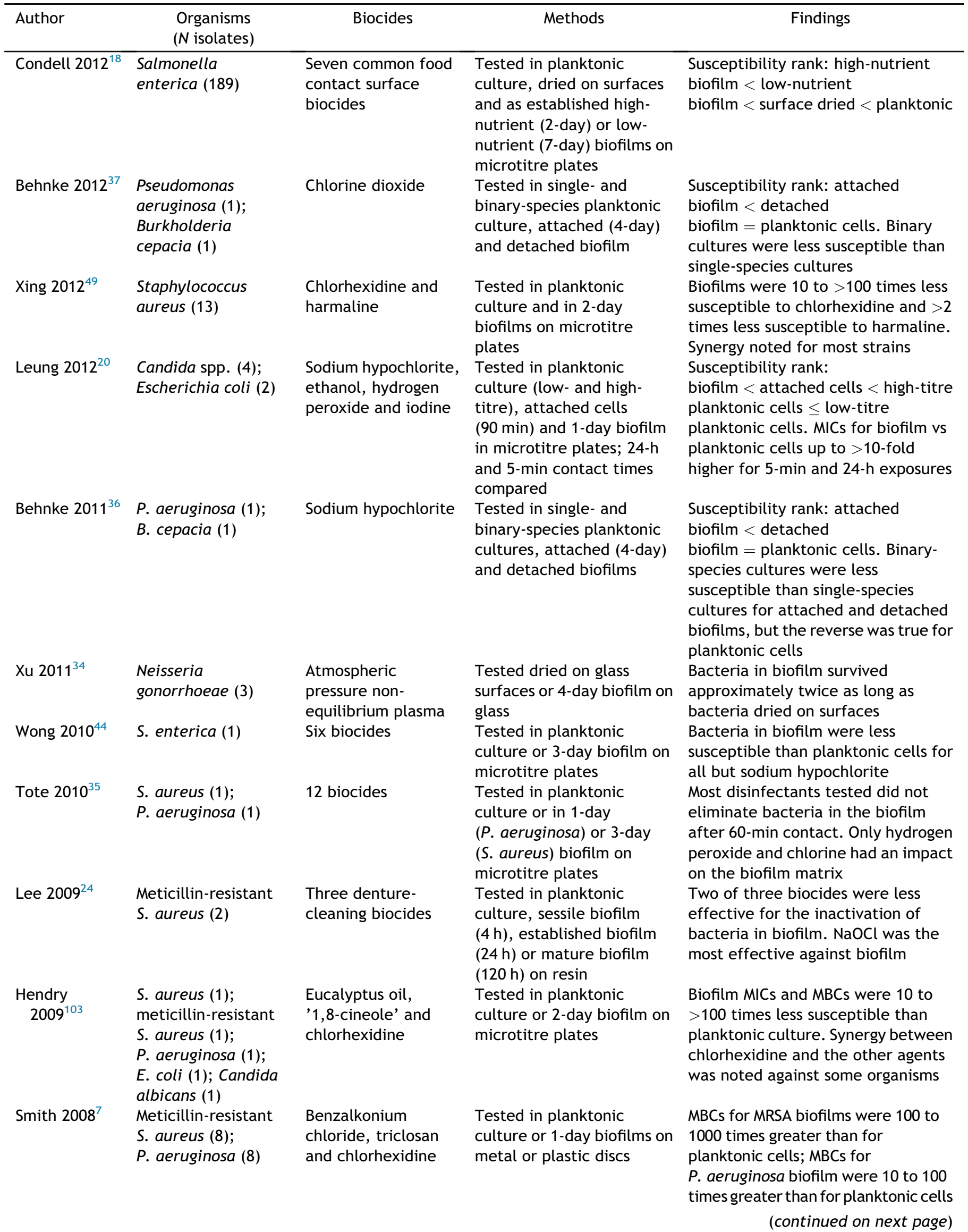


Table I (continued)

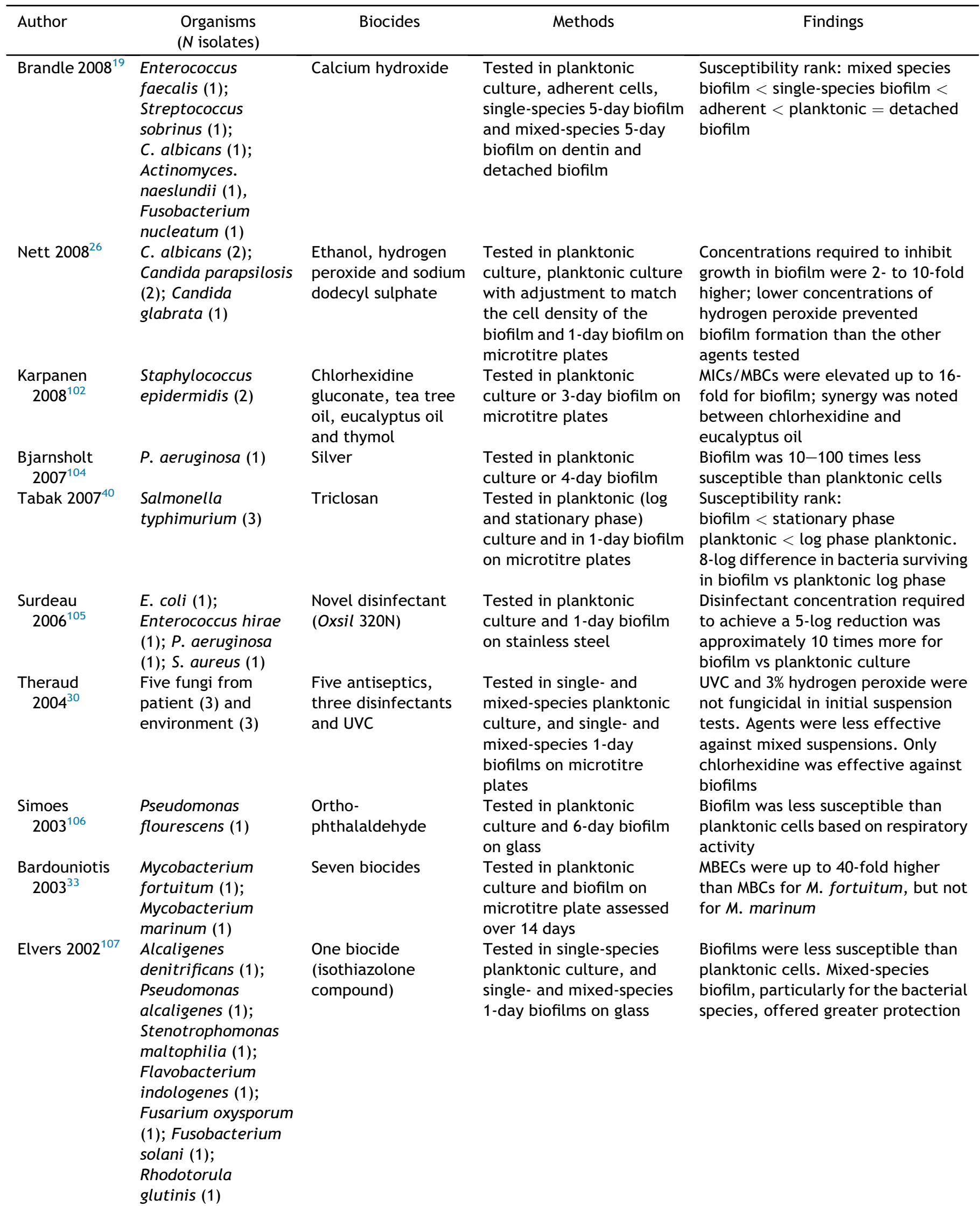


Table I (continued)

\begin{tabular}{|c|c|c|c|c|}
\hline Author & $\begin{array}{l}\text { Organisms } \\
\text { ( } N \text { isolates) }\end{array}$ & Biocides & Methods & Findings \\
\hline Peng $2002^{31}$ & Bacillus cereus (1) & $\begin{array}{l}\text { Sodium hypochlorite } \\
\text { and quaternary } \\
\text { ammonium } \\
\text { compounds }\end{array}$ & $\begin{array}{l}\text { Tested in planktonic } \\
\text { culture, attached to } \\
\text { stainless steel chips }(4 \mathrm{~h}) \\
\text { and } 8 \text {-day biofilm on } \\
\text { stainless steel with or } \\
\text { without milk }\end{array}$ & $\begin{array}{l}\text { Susceptibility rank: milk biofilm } \\
<\text { biofilm }<\text { attached }<\text { planktonic. } \\
5 \text {-log difference between planktonic } \\
\text { cells and milk biofilm }\end{array}$ \\
\hline $\begin{array}{l}\text { Bardouniotis } \\
2001^{108}\end{array}$ & $\begin{array}{l}\text { Mycobacterium } \\
\text { phlei (1) }\end{array}$ & Seven biocides & $\begin{array}{l}\text { Tested in planktonic } \\
\text { culture and } 5 \text {-day biofilm } \\
\text { on microtitre plate }\end{array}$ & $\begin{array}{l}\text { MBECs were higher than MBCs after } \\
30 \text {-min and } 120 \text {-min exposure to } \\
\text { most agents tested }\end{array}$ \\
\hline Joseph $2001^{32}$ & Salmonella spp. (2) & Chlorine and iodine & $\begin{array}{l}\text { Tested in planktonic } \\
\text { culture and } 10 \text {-day biofilms } \\
\text { on plastic, cement and } \\
\text { stainless steel }\end{array}$ & $\begin{array}{l}\text { Biofilms were less susceptible to } \\
\text { both disinfectants; survival time no } \\
\text { more than } 10 \text { min in suspension } \\
\text { vs }>25 \text { min in biofilm }\end{array}$ \\
\hline $\begin{array}{l}\text { Cochran } \\
2000^{29}\end{array}$ & P. aeruginosa (1) & $\begin{array}{l}\text { Monochloramine and } \\
\text { hydrogen peroxide }\end{array}$ & $\begin{array}{l}\text { Tested in planktonic } \\
\text { culture and } 3 \text {-h to } 3 \text {-day } \\
\text { biofilms on alginate beads } \\
\text { and glass slides }\end{array}$ & $\begin{array}{l}\text { Biofilms were less susceptible to } \\
\text { both disinfectants. Reduced } \\
\text { diffusion of biocide in biofilm did not } \\
\text { explain reduced susceptibility }\end{array}$ \\
\hline Elasri $1999^{53}$ & P. aeruginosa (1) & UVA, UVB and UVC & $\begin{array}{l}\text { Strain tested in planktonic } \\
\text { culture or biofilm in } \\
\text { alginate beads assessed } \\
\text { over } 1 \text { day }\end{array}$ & $\begin{array}{l}\text { Biofilm transmitted only a small } \\
\text { amount of UV radiation ( } 13 \% \text { of UVC, } \\
31 \% \text { of UVB and } 33 \% \text { of UVA), } \\
\text { meaning biofilm was less susceptible } \\
\text { than planktonic cells }\end{array}$ \\
\hline Das $1998^{43}$ & $\begin{array}{l}\text { S. epidermidis (1); } \\
\text { E. coli }(1)\end{array}$ & Five biocides & $\begin{array}{l}\text { Tested in planktonic } \\
\text { culture and } 6-24-\mathrm{h} \text { biofilms } \\
\text { on microtitre plates }\end{array}$ & $\begin{array}{l}\text { Biofilms were up to } 33 \text {-fold less } \\
\text { susceptible to the disinfectants } \\
\text { tested, apart from chloroxylenol and } \\
\text { cetrimide ( } E \text {. coli only) }\end{array}$ \\
\hline $\begin{array}{l}\text { Stewart } \\
1998^{45}\end{array}$ & $\begin{array}{l}\text { Enterobacter } \\
\text { aerogenes (1) }\end{array}$ & Four biocides & $\begin{array}{l}\text { Tested in planktonic } \\
\text { culture and high- and low- } \\
\text { density biofilms on alginate } \\
\text { beads assessed over } 5 \mathrm{~h}\end{array}$ & $\begin{array}{l}\text { Susceptibility rank: high-density } \\
\text { biofilm }<\text { low-density } \\
\text { biofilm }<\text { planktonic }\end{array}$ \\
\hline Yu $1993^{42}$ & $\begin{array}{l}\text { Klebsiella } \\
\text { pneumoniae (1) }\end{array}$ & $\begin{array}{l}\text { Sodium hypochlorite } \\
\text { and monochloramine }\end{array}$ & $\begin{array}{l}\text { Tested in planktonic } \\
\text { culture and biofilm on } \\
\text { stainless steel discs }\end{array}$ & $\begin{array}{l}\text { No difference identified between } \\
\text { planktonic and biofilm cells }\end{array}$ \\
\hline Eginton $1998^{56}$ & $\begin{array}{l}\text { S. epidermidis }(1) \\
\text { P. aeruginosa }(1)\end{array}$ & $\begin{array}{l}\text { Sodium hypochlorite } \\
\text { and dodigen; SDS and } \\
\text { Tween-80 }\end{array}$ & $\begin{array}{l}\text { Tested in planktonic } \\
\text { culture and } 16-\mathrm{h} \text { biofilms } \\
\text { on glass and stainless steel }\end{array}$ & $\begin{array}{l}\text { Biofilms were up to }>1000 \text {-fold less } \\
\text { susceptible than planktonic cells; } \\
\text { attachment to the surfaces was } \\
\text { loosened }\end{array}$ \\
\hline $\begin{array}{l}\text { LeChevallier } \\
1988^{25}\end{array}$ & $\begin{array}{l}\text { Pseudomonas } \\
\text { picketti, } \\
\text { Pseudomonas } \\
\text { paucimobilis } \\
\text { Moraxella }{ }^{a} \text {; } \\
\text { K. pneumoniae (1) }\end{array}$ & $\begin{array}{l}\text { Hypochlorous acid, } \\
\text { hypochlorite, } \\
\text { chlorine dioxide and } \\
\text { monochloramine }\end{array}$ & $\begin{array}{l}\text { Tested in planktonic } \\
\text { culture and 3-week biofilms } \\
\text { on granular activated } \\
\text { carbon, metal or glass }\end{array}$ & $\begin{array}{l}\text { Biofilms were } 150 \text { to } 3000 \text { times less } \\
\text { susceptible to hypochlorous acid, } \\
\text { and } 2 \text { - to } 100 \text {-fold less susceptible to } \\
\text { monochloramine }\end{array}$ \\
\hline
\end{tabular}

$\overline{M B C}$, minimum bactericidal concentration; MIC, minimum inhibitory concentration; MBEC, minimal biofilm eradicating concentration; UV, ultraviolet.

Search strategy: Pubmed search for 'susceptibility planktonic biofilm biocide' performed on $15^{\text {th }}$ November 2013 . Of 44 results, 35 were selected for review and 21 were included. A further 10 articles were included following review of the reference lists. Articles were included if they tested organisms and biocides relevant to disinfection in healthcare facilities, and included data comparing planktonic with surfaceattached and/or biofilm mode susceptibility.

a Population from de-ionized water system: composition $70 \%$ P. picketti; $18 \%$ Moraxella spp.; $12 \%$ P. paucimobilis.

effective than chlorhexidine for inactivating Enterococcus faecium and MRSA in biofilms, ${ }^{24,50}$ whereas chlorhexidine was found to be effective against yeast biofilms when sodium hypochlorite was not effective. ${ }^{30}$ In general, oxidizing agents target multiple biofilm components and microbial targets, whereas other biocides such as chlorhexidine only target cell wall components; thus, oxidizing agents tend to have a higher level of efficacy against biofilms. ${ }^{20,24,35,49,50}$ The variations in performance of biocides under different experimental conditions may have implications for practice, where the same biocide could have a different impact on biofilms in different settings. 
Comparing biocides may be further confounded by the 'dose-response' type relationship that has been shown between biofilm susceptibility and biocide concentration. ${ }^{35,51,52}$ For example, one study showed that $10 \%$ hydrogen peroxide was considerably more effective for inactivating bacteria in biofilms compared with $6 \%$ hydrogen peroxide. ${ }^{51}$ Biofilms have also been shown to reduce the susceptibility of microbes to physical processes such as exposure to ultraviolet (UV) radiation, most likely due to poor penetration of UV into the biofilm. ${ }^{53}$ This may have implications for automated room disinfection systems using UV radiation. ${ }^{54}$ To the authors' knowledge, no studies have evaluated the impact of hydrogenperoxide-based automated room disinfection systems against biofilms, although emerging data suggest that liquid hydrogen peroxide, as an oxidizing agent, targets both the biofilm matrix and microbes in the biofilm. ${ }^{35}$

Aside from the inactivation of microbes attached to surfaces, the chemical properties of biocides also seem to be important in terms of preventing, promoting or dismantling biofilms. ${ }^{26,35,55}$ One study showed that only sodium hypochlorite and hydrogen peroxide damaged both the bacteria within the biofilm and the biofilm matrix itself. ${ }^{35}$ Also, hydrogen peroxide was more effective than other agents at preventing Candida spp. biofilm formation. ${ }^{26}$ In another study, exposure to chlorhexidine and benzalkonium chloride inhibited biofilm formation for $E$. coli, K. pneumoniae and $P$. aeruginosa, but promoted biofilm formation in Staphylococcus epidermidis, suggesting that microbial factors are important. ${ }^{55}$ It is possible, therefore, that one microbe in a biofilm may be inactivated by a biocide, but another less susceptible microbe may survive and then grow to replace the microbe that was inactivated.

\section{Antibiotic susceptibility}

Bacteria in biofilms are usually less susceptible to antibiotics than bacteria in planktonic culture, and many of the mechanisms for reduced susceptibility to biocides and antibiotics are shared. ${ }^{5,6}$ Furthermore, bacteria acquired from surfaces in biofilm mode with reduced biocide susceptibility may retain reduced susceptibility to antibiotics.

\section{Physical removal}

The protected mode of growth offers physical protection to cells within biofilms, and makes the physical breakdown of biofilms challenging. ${ }^{5}$ Although biofilm attachment appears to be loosened by some biocides, ${ }^{35,56}$ several studies have illustrated how difficult it can be to remove bacteria in biofilms through cleaning and/or inactivation through disinfection. For example, regular and extended detergent cleaning did not remove a Bacillus cereus biofilm in vitro; a modified procedure including heating to $70^{\circ} \mathrm{C}$ was required. ${ }^{31}$ Clearly, heating to $70^{\circ} \mathrm{C}$ is not feasible for the cleaning and disinfection of hospital surfaces in clinical areas. Similarly, attached, viable Pseudomonas fragi were detected on stainless steel surfaces after two cleaning and disinfection procedures were tested under 'worstcase' conditions at $50 \%$ in-use disinfectant concentrations. ${ }^{57}$ An acid-detergent-based method was more effective at removing attached cells than an alkaline-detergent-based method. However, these studies were performed using mature biofilms which may not be representative of the biofilms present on hospital surfaces.

Surface-attached cells and biofilms are clearly not the only reason for failures in hospital disinfection, given the difficulty in achieving adequate distribution and contact time using manual methods. ${ }^{11,13,54,58}$ However, both reduced biocide susceptibility (Table I) and increasing resilience to physical removal by cleaning are likely to contribute to failures in hospital cleaning. This could partly explain why disinfectants that are effective for the inactivation of planktonic bacteria in laboratory tests are not effective for the eradication of a considerably lower load of the same bacterial species from hospital surfaces. ${ }^{11,13,58-60}$ In support of this, it is noteworthy that the biofilms identified by Vickery et al. were on surfaces that had been cleaned with detergent and then disinfected using 500 ppm chlorine. ${ }^{15}$ These findings may have implications for infection control practices within hospitals, and on the choice of appropriate disinfectants used to decontaminate surfaces. ${ }^{11,13,54}$

The presence of biofilms on dry hospital surfaces could also interfere with attempts to recover microbes through environmental sampling. ${ }^{15,61-63}$ This could mean that an environmental reservoir of a pathogen remains undetected, or the concentration of contamination and degree of associated risk is underestimated.

\section{Persistence}

Vegetative bacteria dried on to surfaces can survive for weeks to months (or more) in vitro, despite the lack of a nutrient source or water (aside from ambient humidity). ${ }^{8,9}$ Biofilms may explain this surprising propensity of vegetative bacteria. $^{8-10}$ This is supported by a recent study which found that biofilm-forming strains of Acinetobacter baumannii survived for longer on dry surfaces than non-biofilm-forming strains (36 vs 15 days; $P<0.001$ ). ${ }^{64}$ In-vitro studies evaluating the persistence of dried inocula did not supply any water or nutrients. ${ }^{8-10,14,65}$ However, in the hospital environment, daily and terminal cleaning or disinfection does provide a supply of water, and some bacteria may be able to metabolize some constituent parts of detergents and even disinfectants, providing a nutrient source for the growth in biofilms. ${ }^{66-69}$

\section{Transfer of plasmids and development of antimicrobial resistance}

Biofilms are suited for horizontal gene dissemination because they are a mixed population at high bacterial density, which facilitates metabolic activity in the harshest environments, albeit at a reduced rate. Horizontal transfer of plasmids does occur through conjugation, as illustrated by the transfer of extended-spectrum $\beta$-lactamase $(C T X-M-15)$ and carbapenemase (NDM-1) plasmids between Enterobacteriaceae when dried on surfaces. ${ }^{70,71}$ Furthermore, the mutation rate (the rate at which DNA replication mistakes occur during cell division) of bacteria in biofilms is increased. ${ }^{6,72}$ Thus, both horizontal transfer of resistance determinants such as plasmids and increased mutation rates could result in the acquisition or denovo development of reduced susceptibility to antimicrobial agents and other important microbial capabilities, such as increased virulence.

\section{Tackling surface-attached cells and biofilms}

Surface-attached cells, especially established biofilms, present a difficult challenge to hospital cleaning and disinfection, 
combining protection from physical removal with reduced susceptibility to biocides (Table I). ${ }^{31,57}$ A number of different approaches are available to tackle surface-attached cells and biofilms. Using physical methods to dislodge detached bacteria, which can be aided by the use of a detergent, can be effective in removing established biofilms and preventing the development of biofilms. ${ }^{5,56,73}$ However, detergent cleaning alone may not be sufficient to remove biofilms. ${ }^{5,15,31,56,61,73}$ Tackling the microbes in the biofilm alone (e.g. using some disinfectants or attempts to interfere with quorum sensing) can be effective, but may not reach microbes protected deep in the biofilm matrix. Tackling the biofilm matrix alone (e.g. using enzymatic digestion) will help to reach microbes protected within the biofilm matrix and interrupt persistence of the biofilm, but will not necessarily have direct microbicidal activity. Thus, tackling both the microbes in the biofilm and the biofilm matrix simultaneously (using oxidizing disinfectants or combination approaches) offers the potential to reach microbes protected deep in the matrix and interrupt the persistence of the biofilm. In addition, some biocides have the ability to reduce biofilm formation, which can be assisted by choosing surface materials that do not readily support biofilm formation.

\section{Biocides and biocide adjuvants}

Differences between biocides appear to influence their activity against bacteria attached to surfaces and may also promote, prevent or dismantle biofilms. Thus, biocides with the highest activity against bacteria attached to surfaces, and ideally those with the ability to prevent biofilm formation and dismantle existing biofilms, should be selected. Emerging data indicate that oxidizing agents may possess more of these properties than other agents. ${ }^{35}$ Similarly, detergent formulations that are better at physical removal should be selected, although there is a paucity of data on the capacity of currently available detergents to address surface-attached cells. ${ }^{73}$

Several novel approaches also warrant consideration as potential additives to hospital detergents or disinfectants to augment their effectiveness against biofilms. Firstly, certain enzymes such as DNase and dispersinB have been shown to dissolve the biofilm matrix. ${ }^{73-78}$ For example, detergents supplemented with high concentrations of enzymes were effective against hydrated biofilms, whereas detergents supplemented with low concentrations of enzymes were not. ${ }^{73}$ Secondly, quorum-sensing inhibitors have proven successful in increasing antimicrobial susceptibility. ${ }^{79-81}$ In one study, drimendiol, a quorum-sensing inhibitor, was found to enhance the effects of copper sulphate on biofilms of Pseudomonas syringae. ${ }^{81}$ Thirdly, recently discovered human antimicrobial peptides also have antibiofilm activities. ${ }^{82-84}$ For example, a range of antimicrobial peptides tested against multi-drug-resistant $A$. baumannii demonstrated direct antimicrobial activity, and enhanced the activity of a range of other antimicrobial agents. ${ }^{82}$

However, the addition of enzymes, quorum-sensing inhibitors or antimicrobial peptides into a cleaning or disinfection solution would result in chemical residues on surfaces with associated health and safety implications, so are not recommended without further study. Another approach is the inclusion of bacteriophages, which have been found to disrupt biofilms. ${ }^{85,86}$ For example, Streptococcus pyogenes biofilms were degraded by PlyC, a bacteriophage-encoded endolysin, which also acted synergistically with a range of antimicrobial agents. ${ }^{86}$ However, the therapeutic use of bacteriophages in human medicine and, by implication, in the clinical environment is controversial due to potential for the rapid development of resistance and the risk that the introduced bacteriophages may play an unintended role in horizontal gene transfer. ${ }^{85,87}$

\section{Surface modification to prevent biofilm formation}

Some surface materials are more prone to biofilm formation than others. ${ }^{71,88} \mathrm{~A}$ recent study reviewed attempts to modify the chemical or physical surface properties of medical devices to inhibit or prevent microbial adhesion. ${ }^{88}$ These include 'liquid glass' (silicon dioxide), Sharklet pattern, ${ }^{89,90}$ advanced polymer coatings [e.g. polyethylene glycol (PEG), superhydrophobic/philic and zwitterionic $]^{91-94}$ and diamond-like carbon films. ${ }^{95}$ Whilst these technologies have the potential to reduce biofilm deposition on hospital surfaces, they are at an early stage of development. The feasibility and costeffectiveness of scaling up these technologies for use on hospital surfaces needs to be evaluated.

Another approach is the implementation of antimicrobial surfaces. Options include metals such as copper and silver, or chemicals such as organosilanes with quaternary ammonium groups and light-activated antimicrobials. ${ }^{12,71,96}$ Copper is the most-studied candidate for antimicrobial surfaces, and has been shown to inactivate microbes and DNA deposited on surfaces and may reduce the transmission of pathogens in the hospital setting. ${ }^{12,71,97}$ However, the presence of a conditioning film can greatly reduce the efficacy of antimicrobial surfaces. ${ }^{98-100}$ Thus, an antimicrobial surface that combines reduced biofilm formation with direct antimicrobial activity is a promising area for future research. Another challenge in developing an antimicrobial surface for hospitals is the requirement for multiple different surface types (from fabric to hard surfaces) with a range of required functions. Thus, there is unlikely to be a single agent or surface structure that is suitable for all applications.

\section{Implications for susceptibility testing}

Surface-attached cells and biofilms are a more accurate reflection of the occurrence of bacteria in nature than planktonic cells. ${ }^{1,101}$ However, planktonic culture remains the current model for many microbiological studies and testing standards including susceptibility testing. ${ }^{1,101}$ Although quantitative surface tests for evaluation of the bactericidal activity of chemical disinfectants do exist (e.g. BS EN 13697:2001), none have been published for EPS-producing biofilms. Future testing should specify the use of surface-attached cells and consider the use of biofilm models to ensure that the disinfectants tested are as effective in the 'real world' as in laboratory tests. ${ }^{1}$ It seems likely that low-nutrient, low-density surface-attached cells would be more appropriate than highnutrient, high-density established biofilms. Most in-vitro studies measured growth over a 24 -h period to evaluate the impact of a chemical biocide to determine the MIC or MBC, using methodology often used to test antibiotic susceptibility (Table I). 7,20,102 One study compared the MICs of four common biocides for $E$. coil and various Candida spp. with a 'contact time' of $5 \mathrm{~min}$ and $24 \mathrm{~h}^{20}$ Unsurprisingly, the concentration required to inhibit growth within 5 min was considerably greater than the concentration required to inhibit growth over 
$24 \mathrm{~h}$. Thus, as biocides are only applied for a short period in practice, evaluating the impact of a biocide over a short contact time as per most published biocide testing standards is more suitable for in-vitro biocide studies than measuring the $M I C$ or MBC when microbes are grown in varying concentrations of biocide.

Further research is required to evaluate the prevalence and composition of biofilms in situ on hard and soft hospital surfaces, to develop in-vitro models that are representative of those likely to be found on hospital surfaces, and to optimize methods to tackle biofilms on hospital surfaces, which may include new cleaning and disinfection agents and adjuvants, new technologies (such as microfibre or automated room disinfection technology), and surface modification. ${ }^{15}$

\section{Conclusion}

Surface-attached cells are likely to be common on dry hospital surfaces, and there is evidence that they also harbour established biofilms. The variety of methods used to create and evaluate in-vitro biofilms makes it difficult to compare studies evaluating antibiofilm biocide activity. Nonetheless, microbes attached to surfaces, especially established biofilms, are less susceptible to chemical biocides, UV radiation and antibiotics than their corresponding planktonic bacteria. The phase of the surface-attached microbes influences susceptibility: attached cells are more susceptible to biocides than established biofilms; low-density, nutrient-limited biofilms make less of an impact on biocide susceptibility than high-density, highnutrient biofilms; and biocides are less effective for inactivating bacteria in mixed-species biofilms than in single-species biofilms. Biocide-specific issues also influence susceptibility in terms of activity against bacteria in biofilms, and the prevention, promotion and dismantling of biofilms. Reduced susceptibility to biocides combined with protection from physical removal through cleaning is likely to contribute to failures in hospital cleaning and disinfection.

Biofilms may explain why vegetative bacteria can survive for unusually long periods (weeks to months) on dry hospital surfaces. Also, the presence of surface-attached bacteria and biofilms is likely to interfere with attempts to recover bacteria from hospital surfaces, and may lead to underestimation of both the prevalence of contamination with pathogens and the number of bacteria that are on surfaces. This has important implications, particularly for hospital outbreak investigation. Biofilms provide a mixed bacterial community where the horizontal transfer of resistance genes may occur. Attempts to tackle surfaceattached microbes and biofilms on hospital surfaces should include: identification and selection of biocide and detergents with the best all-round performance, including the ability to inactivate surface-attached cells and biofilms; ensuring that invitro tests are developed to model surface-attached microbes likely to be encountered in the field; harnessing surface science to develop a hospital environment that reduces the chance of biofilm formation; and further research to develop novel approaches to augment the activity of biocides against surfaceattached microbes, including established biofilms.

\section{Conflict of interest statement}

JAO is employed part-time by Bioquell, and JAGS, JC and SY are employed by Bioquell. All other authors have no conflicts of interest to declare.
Funding source

None.

\section{References}

1. Lindsay D, von Holy A. Bacterial biofilms within the clinical setting: what healthcare professionals should know. J Hosp Infect 2006;64:313-325.

2. Hall-Stoodley L, Stoodley P. Biofilm formation and dispersal and the transmission of human pathogens. Trends Microbiol 2005;13:7-10.

3. Hall-Stoodley L, Costerton JW, Stoodley P. Bacterial biofilms: from the natural environment to infectious diseases. Nat Rev Microbiol 2004;2:95-108.

4. Loveday HP, Wilson J, Kerr K, Pitchers R, Walker JT, Browne J. Pseudomonas infection and healthcare water systems - a rapid systematic review. J Hosp Infect 2014;86:7-15.

5. Mah TF, O'Toole GA. Mechanisms of biofilm resistance to antimicrobial agents. Trends Microbiol 2001;9:34-39.

6. Hoiby N, Bjarnsholt T, Givskov M, Molin S, Ciofu O. Antibiotic resistance of bacterial biofilms. Int $J$ Antimicrob Agents 2010;35:322-332.

7. Smith K, Hunter IS. Efficacy of common hospital biocides with biofilms of multi-drug resistant clinical isolates. J Med Microbiol 2008;57:966-973.

8. Otter JA, French GL. Survival of nosocomial bacteria and spores on surfaces and inactivation by hydrogen peroxide vapor. J Clin Microbiol 2009;47:205-207.

9. Kramer A, Schwebke I, Kampf G. How long do nosocomial pathogens persist on inanimate surfaces? A systematic review. BMC Infect Dis 2006;6:130.

10. Wagenvoort JH, De Brauwer El, Penders RJ, Willems RJ, Top J, Bonten MJ. Environmental survival of vancomycin-resistant Enterococcus faecium. J Hosp Infect 2011;77:282-283.

11. Otter JA, Yezli S, French GL. The role played by contaminated surfaces in the transmission of nosocomial pathogens. Infect Control Hosp Epidemiol 2011;32:687-699.

12. Salgado CD, Sepkowitz KA, John JF, et al. Copper surfaces reduce the rate of healthcare-acquired infections in the intensive care unit. Infect Control Hosp Epidemiol 2013;34:479-486.

13. Donskey CJ. Does improving surface cleaning and disinfection reduce health care-associated infections? Am J Infect Control 2013;41:S12-S19.

14. Wagenvoort JH, Joosten EJ. An outbreak Acinetobacter baumannii that mimics MRSA in its environmental longevity. J Hosp Infect 2002;52:226-227.

15. Vickery K, Deva A, Jacombs A, Allan J, Valente P, Gosbell IB. Presence of biofilm containing viable multiresistant organisms despite terminal cleaning on clinical surfaces in an intensive care unit. J Hosp Infect 2012;80:52-55.

16. Yezli S, Otter JA. Does the discovery of biofilms on dry hospital environmental surfaces change the way we think about hospital disinfection? J Hosp Infect 2012;81:293-294.

17. Smith K, Perez A, Ramage G, Gemmell CG, Lang S. Comparison of biofilm-associated cell survival following in vitro exposure of meticillin-resistant Staphylococcus aureus biofilms to the antibiotics clindamycin, daptomycin, linezolid, tigecycline and vancomycin. Int J Antimicrob Agents 2009;33:374-378.

18. Condell O, Iversen C, Cooney S, et al. Efficacy of biocides used in the modern food industry to control Salmonella enterica, and links between biocide tolerance and resistance to clinically relevant antimicrobial compounds. Appl Environ Microbiol 2012;78:3087-3097.

19. Brandle $N$, Zehnder M, Weiger R, Waltimo T. Impact of growth conditions on susceptibility of five microbial species to alkaline stress. J Endod 2008;34:579-582.

20. Leung CY, Chan YC, Samaranayake LP, Seneviratne CJ. Biocide resistance of Candida and Escherichia coli biofilms is associated with higher antioxidative capacities. J Hosp Infect 2012;81:79-86. 
21. Parsek MR, Greenberg EP. Sociomicrobiology: the connections between quorum sensing and biofilms. Trends Microbiol 2005; 13:27-33.

22. Stewart PS. Diffusion in biofilms. J Bacteriol 2003;185:1485-1491.

23. Keren I, Kaldalu N, Spoering A, Wang Y, Lewis K. Persister cells and tolerance to antimicrobials. FEMS Microbiol Lett 2004;230:13-18.

24. Lee D, Howlett J, Pratten J, et al. Susceptibility of MRSA biofilms to denture-cleansing agents. FEMS Microbiol Lett 2009;291:241-246.

25. LeChevallier MW, Cawthon CD, Lee RG. Inactivation of biofilm bacteria. Appl Environ Microbiol 1988;54:2492-2499.

26. Nett JE, Guite KM, Ringeisen A, Holoyda KA, Andes DR. Reduced biocide susceptibility in Candida albicans biofilms. Antimicrob Agents Chemother 2008;52:3411-3413.

27. Watamoto T, Samaranayake LP, Egusa H, Yatani $H$, Samaranayke YH, Seneviratne CJ. Susceptibility of Candida albicans filamentation-defective mutants to clinical biocides. J Hosp Infect 2010;74:189-191.

28. Seneviratne CJ, Jin LJ, Samaranayake YH, Samaranayake LP. Cell density and cell aging as factors modulating antifungal resistance of Candida albicans biofilms. Antimicrob Agents Chemother 2008;52:3259-3266.

29. Cochran WL, McFeters GA, Stewart PS. Reduced susceptibility of thin Pseudomonas aeruginosa biofilms to hydrogen peroxide and monochloramine. J Appl Microbiol 2000;88:22-30.

30. Theraud M, Bedouin Y, Guiguen C, Gangneux JP. Efficacy of antiseptics and disinfectants on clinical and environmental yeast isolates in planktonic and biofilm conditions. J Med Microbiol 2004;53:1013-1018.

31. Peng JS, Tsai WC, Chou CC. Inactivation and removal of Bacillus cereus by sanitizer and detergent. Int $J$ Food Microbiol 2002;77:11-18.

32. Joseph B, Otta SK, Karunasagar I, Karunasagar I. Biofilm formation by Salmonella spp. on food contact surfaces and their sensitivity to sanitizers. Int J Food Microbiol 2001;64:367-372.

33. Bardouniotis E, Ceri H, Olson ME. Biofilm formation and biocide susceptibility testing of Mycobacterium fortuitum and Mycobacterium marinum. Curr Microbiol 2003;46:28-32.

34. Xu L, Tu Y, Yu Y, Tan M, Li J, Chen H. Augmented survival of Neisseria gonorrhoeae within biofilms: exposure to atmospheric pressure non-thermal plasmas. Eur J Clin Microbiol Infect Dis $2011 ; 30: 25-31$.

35. Tote K, Horemans T, Vanden Berghe D, Maes L, Cos P. Inhibitory effect of biocides on the viable masses and matrices of Staphylococcus aureus and Pseudomonas aeruginosa biofilms. Appl Environ Microbiol 2010;76:3135-3142.

36. Behnke S, Parker AE, Woodall D, Camper AK. Comparing the chlorine disinfection of detached biofilm clusters with those of sessile biofilms and planktonic cells in single- and dual-species cultures. Appl Environ Microbiol 2011;77:7176-7184.

37. Behnke S, Camper AK. Chlorine dioxide disinfection of single and dual species biofilms, detached biofilm and planktonic cells. Biofouling 2012;28:635-647.

38. Bjergbaek LA, Haagensen JA, Molin S, Roslev P. Effect of oxygen limitation and starvation on the benzalkonium chloride susceptibility of Escherichia coli. J Appl Microbiol 2008;105:1310-1317.

39. Field TR, White A, Elborn JS, Tunney MM. Effect of oxygen limitation on the in vitro antimicrobial susceptibility of clinical isolates of Pseudomonas aeruginosa grown planktonically and as biofilms. Eur J Clin Microbiol Infect Dis 2005;24:677-687.

40. Tabak M, Scher K, Hartog E, et al. Effect of triclosan on Salmonella typhimurium at different growth stages and in biofilms. FEMS Microbiol Lett 2007;267:200-206.

41. Smith K, Gemmell CG, Hunter IS. The association between biocide tolerance and the presence or absence of qac genes among hospital-acquired and community-acquired MRSA isolates. J Antimicrob Chemother 2008;61:78-84.
42. Yu FP, Pyle BH, McFeters GA. A direct viable count method for the enumeration of attached bacteria and assessment of biofilm disinfection. J Microbiol Methods 1993;17:167-180.

43. Das JR, Bhakoo M, Jones MV, Gilbert P. Changes in the biocide susceptibility of Staphylococcus epidermidis and Escherichia coli cells associated with rapid attachment to plastic surfaces. J Appl Microbiol 1998;84:852-858.

44. Wong HS, Townsend KM, Fenwick SG, Trengove RD, O'Handley RM. Comparative susceptibility of planktonic and 3day-old Salmonella typhimurium biofilms to disinfectants. J Appl Microbiol 2010;108:2222-2228.

45. Stewart PS, Grab L, Diemer JA. Analysis of biocide transport limitation in an artificial biofilm system. J Appl Microbiol 1998;85:495-500.

46. van de Mortel M, Halverson LJ. Cell envelope components contributing to biofilm growth and survival of Pseudomonas putida in low-water-content habitats. Mol Microbiol 2004;52:735-750.

47. Flemming HC, Wingender J. The biofilm matrix. Nat Rev Microbiol 2010;8:623-633.

48. Bridier A, Sanchez-Vizuete Mdel P, Le Coq D, et al. Biofilms of a Bacillus subtilis hospital isolate protect Staphylococcus aureus from biocide action. PLoS One 2012;7:e44506.

49. Xing M, Shen F, Liu L, et al. Antimicrobial efficacy of the alkaloid harmaline alone and in combination with chlorhexidine digluconate against clinical isolates of Staphylococcus aureus grown in planktonic and biofilm cultures. Lett Appl Microbiol 2012;54:475-482.

50. Williamson AE, Cardon JW, Drake DR. Antimicrobial susceptibility of monoculture biofilms of a clinical isolate of Enterococcus faecalis. J Endod 2009;35:95-97.

51. Yun HS, Kim Y, Oh S, Jeon WM, Frank JF, Kim SH. Susceptibility of Listeria monocytogenes biofilms and planktonic cultures to hydrogen peroxide in food processing environments. Biosci Biotechnol Biochem 2012;76:2008-2013.

52. Peeters E, Nelis HJ, Coenye T. Evaluation of the efficacy of disinfection procedures against Burkholderia cenocepacia biofilms. J Hosp Infect 2008;70:361-368.

53. Elasri MO, Miller RV. Study of the response of a biofilm bacterial community to UV radiation. Appl Environ Microbiol 1999;65:2025-2031.

54. Otter JA, Yezli S, Perl TM, Barbut F, French GL. Is there a role for 'no-touch' automated room disinfection systems in infection prevention and control? J Hosp Infect 2013;83:1-13.

55. Houari A, Di Martino P. Effect of chlorhexidine and benzalkonium chloride on bacterial biofilm formation. Lett Appl Microbiol 2007;45:652-656.

56. Eginton PJ, Holah J, Allison DG, Handley PS, Gilbert P. Changes in the strength of attachment of micro-organisms to surfaces following treatment with disinfectants and cleansing agents. Lett Appl Microbiol 1998;27:101-105.

57. Stone LS, Zottola EA. Effect of cleaning and sanitizing on the attachment of Pseudomonas fragi to stainless steel. J Food Sci 1985;50:951-956.

58. Manian FA, Griesenauer S, Senkel D, et al. Isolation of Acinetobacter baumannii complex and methicillin-resistant Staphylococcus aureus from hospital rooms following terminal cleaning and disinfection: can we do better? Infect Control Hosp Epidemiol 2011;32:667-672.

59. Goodman ER, Platt R, Bass R, Onderdonk AB, Yokoe DS, Huang SS. Impact of an environmental cleaning intervention on the presence of methicillin-resistant Staphylococcus aureus and vancomycin-resistant enterococci on surfaces in intensive care unit rooms. Infect Control Hosp Epidemiol 2008;29:593-599.

60. Wilcox MH, Fawley WN, Wigglesworth N, Parnell P, Verity P, Freeman J. Comparison of the effect of detergent versus hypochlorite cleaning on environmental contamination and incidence of Clostridium difficile infection. J Hosp Infect 2003;54:109-114.

61. French GL, Otter JA, Shannon KP, Adams NM, Watling D, Parks MJ. Tackling contamination of the hospital environment by 
methicillin-resistant Staphylococcus aureus (MRSA): a comparison between conventional terminal cleaning and hydrogen peroxide vapour decontamination. J Hosp Infect 2004;57:31-37.

62. Zanetti G, Blanc DS, Federli I, et al. Importation of Acinetobacter baumannii into a burn unit: a recurrent outbreak of infection associated with widespread environmental contamination. Infect Control Hosp Epidemiol 2007;28:723-725.

63. Boyce JM, Havill NL, Havill HL, Mangione E, Dumigan DG, Moore BA. Comparison of fluorescent marker systems with 2 quantitative methods of assessing terminal cleaning practices. Infect Control Hosp Epidemiol 2011;32:1187-1193.

64. Espinal P, Marti S, Vila J. Effect of biofilm formation on the survival of Acinetobacter baumannii on dry surfaces. J Hosp Infect 2012;80:56-60.

65. Wagenvoort JH, Sluijsmans W, Penders RJ. Better environmental survival of outbreak vs. sporadic MRSA isolates. J Hosp Infect 2000;45:231-234.

66. Weber DJ, Rutala WA, Sickbert-Bennett EE. Outbreaks associated with contaminated antiseptics and disinfectants. Antimicrob Agents Chemother 2007; 51:4217-4224.

67. Basu A, Dixit SS, Phale PS. Metabolism of benzyl alcohol via catechol ortho-pathway in methylnaphthalene-degrading Pseudomonas putida CSV86. Appl Microbiol Biotechnol 2003;62:579-585.

68. Gottsching A, Schmidt S. Productive degradation of the biocide benzylbenzoate by Acinetobacter sp. strain AG1 isolated from the River Elbe. Res Microbiol 2007;158:251-257.

69. Ying GG. Fate, behavior and effects of surfactants and their degradation products in the environment. Environ Int 2006;32:417-431.

70. Molin S, Tolker-Nielsen T. Gene transfer occurs with enhanced efficiency in biofilms and induces enhanced stabilisation of the biofilm structure. Curr Opin Biotechnol 2003;14:255-261.

71. Warnes SL, Highmore CJ, Keevil CW. Horizontal transfer of antibiotic resistance genes on abiotic touch surfaces: implications for public health. MBio 2012;3:e00489-e00512.

72. Driffield K, Miller K, Bostock JM, O’Neill AJ, Chopra I. Increased mutability of Pseudomonas aeruginosa in biofilms. J Antimicrob Chemother 2008;61:1053-1056.

73. Vickery K, Pajkos A, Cossart Y. Removal of biofilm from endoscopes: evaluation of detergent efficiency. Am J Infect Control 2004;32:170-176.

74. Brindle ER, Miller DA, Stewart PS. Hydrodynamic deformation and removal of Staphylococcus epidermidis biofilms treated with urea, chlorhexidine, iron chloride, or DispersinB. Biotechnol Bioeng 2011;108:2968-2977.

75. Kaplan JB, LoVetri K, Cardona ST, et al. Recombinant human DNase I decreases biofilm and increases antimicrobial susceptibility in staphylococci. J Antibiot (Tokyo) 2012;65:73-77.

76. Li W, Liu H, Xu Q. Extracellular dextran and DNA affect the formation of Enterococcus faecalis biofilms and their susceptibility to 2\% chlorhexidine. J Endod 2012;38:894-898.

77. Latimer J, Forbes S, McBain AJ. Attenuated virulence and biofilm formation in Staphylococcus aureus following sublethal exposure to triclosan. Antimicrob Agents Chemother 2012;56:3092-3100.

78. Alipour M, Suntres ZE, Omri A. Importance of DNase and alginate lyase for enhancing free and liposome encapsulated aminoglycoside activity against Pseudomonas aeruginosa. J Antimicrob Chemother 2009;64:317-325.

79. Liaqat I, Bachmann RT, Sabri AN, Edyvean RG, Biggs CA. Investigating the effect of patulin, penicillic acid and EDTA on biofilm formation of isolates from dental unit water lines. Appl Microbiol Biotechnol 2008;81:349-358.

80. Bjarnsholt T, Jensen PO, Rasmussen TB, et al. Garlic blocks quorum sensing and promotes rapid clearing of pulmonary Pseudomonas aeruginosa infections. Microbiology 2005;151:3873-3880.

81. Paza C, Carcamo G, Silva M, Becerra J, Urrutia H, Sossa K. Drimendiol, a drimane sesquiterpene with quorum sensing inhibition activity. Nat Prod Commun 2013;8:147-148.
82. Gopal R, Kim YG, Lee JH, et al. Synergistic effects and antibiofilm properties of chimeric peptides against multidrug-resistant Acinetobacter baumannii strains. Antimicrob Agents Chemother 2014;58:1622-1629.

83. Feng X, Sambanthamoorthy K, Palys T, Paranavitana C. The human antimicrobial peptide LL-37 and its fragments possess both antimicrobial and antibiofilm activities against multidrug. resistant Acinetobacter baumannii. Peptides 2013;49:131-137.

84. Forbes S, McBain AJ, Felton-Smith S, Jowitt TA, Birchenough HL, Dobson CB. Comparative surface antimicrobial properties of synthetic biocides and novel human apolipoprotein $\mathrm{E}$ derived antimicrobial peptides. Biomaterials 2013;34:5453-5464.

85. Sillankorva S, Azeredo J. Bacteriophage attack as an anti-biofilm strategy. Methods Mol Biol 2014;1147:277-285.

86. Shen Y, Koller T, Kreikemeyer B, Nelson DC. Rapid degradation of Streptococcus pyogenes biofilms by PlyC, a bacteriophageencoded endolysin. J Antimicrob Chemother 2013;68:1818-1824.

87. Lu TK, Koeris MS. The next generation of bacteriophage therapy. Curr Opin Microbiol 2011;14:524-531.

88. Desrousseaux C, Sautou V, Descamps S, Traore O. Modification of the surfaces of medical devices to prevent microbial adhesion and biofilm formation. J Hosp Infect 2013;85:87-93.

89. Chung KK, Schumacher JF, Sampson EM, Burne RA, Antonelli PJ, Brennan AB. Impact of engineered surface microtopography on biofilm formation of Staphylococcus aureus. Biointerphases 2007;2:89-94.

90. Reddy ST, Chung KK, MCDaniel CJ, Darouiche RO, Landman J, Brennan AB. Micropatterned surfaces for reducing the risk of catheter-associated urinary tract infection: an in vitro study on the effect of Sharklet micropatterned surfaces to inhibit bacterial colonization and migration of uropathogenic Escherichia coli. J Endourol 2011;25:1547-1552.

91. Park KD, Kim YS, Han DK, et al. Bacterial adhesion on PEG modified polyurethane surfaces. Biomaterials 1998;19:851-859.

92. Hou S, Burton EA, Simon KA, Blodgett D, Luk YY, Ren D. Inhibition of Escherichia coli biofilm formation by self-assembled monolayers of functional alkanethiols on gold. Appl Environ Microbiol 2007; 73:4300-4307.

93. Hirota K, Murakami K, Nemoto K, Miyake Y. Coating of a surface with 2-methacryloyloxyethyl phosphorylcholine (MPC) copolymer significantly reduces retention of human pathogenic microorganisms. FEMS Microbiol Lett 2005;248:37-45.

94. Cheng G, Zhang Z, Chen S, Bryers JD, Jiang S. Inhibition of bacterial adhesion and biofilm formation on zwitterionic surfaces. Biomaterials 2007;28:4192-4199.

95. Liu C, Zhao Q, Liu Y, Wang S, Abel EW. Reduction of bacterial adhesion on modified DLC coatings. Colloids Surf B Biointerfaces 2008;61:182-187.

96. Humphreys H. Self-disinfecting and microbiocide-impregnated surfaces and fabrics: what potential in interrupting the spread of healthcare-associated infection? Clin Infect Dis 2014; 58:848-853.

97. Grass G, Rensing C, Solioz M. Metallic copper as an antimicrobial surface. Appl Environ Microbiol 2011;77:1541-1547.

98. Ojeil M, Jermann C, Holah J, Denyer SP, Maillard JY. Evaluation of new in vitro efficacy test for antimicrobial surface activity reflecting UK hospital conditions. J Hosp Infect 2013;85:274-281.

99. O'Gorman J, Humphreys H. Application of copper to prevent and control infection. Where are we now? J Hosp Infect 2012;81:217-223.

100. Airey P, Verran J. Potential use of copper as a hygienic surface; problems associated with cumulative soiling and cleaning. J Hosp Infect 2007;67:271-277.

101. Parsek MR, Fuqua C. Biofilms 2003: emerging themes and challenges in studies of surface-associated microbial life. J Bacteriol 2004; 186:4427-4440.

102. Karpanen TJ, Worthington T, Hendry ER, Conway BR, Lambert PA. Antimicrobial efficacy of chlorhexidine digluconate alone and in combination with eucalyptus oil, tea tree oil and 
thymol against planktonic and biofilm cultures of Staphylococcus epidermidis. J Antimicrob Chemother 2008;62:1031-1036.

103. Hendry ER, Worthington T, Conway BR, Lambert PA. Antimicrobial efficacy of eucalyptus oil and 1,8-cineole alone and in combination with chlorhexidine digluconate against microorganisms grown in planktonic and biofilm cultures. J Antimicrob Chemother 2009;64:1219-1225.

104. Bjarnsholt T, Kirketerp-Moller K, Kristiansen S, et al. Silver against Pseudomonas aeruginosa biofilms. APMIS 2007;115:921-928.

105. Surdeau N, Laurent-Maquin D, Bouthors S, Gelle MP. Sensitivity of bacterial biofilms and planktonic cells to a new antimicrobial agent, Oxsil 320N. J Hosp Infect 2006;62:487-493.
106. Simoes M, Carvalho H, Pereira MO, Vieira MJ. Studies on the behaviour of Pseudomonas fluorescens biofilms after orthophthalaldehyde treatment. Biofouling 2003;19:151-157.

107. Elvers KT, Leeming K, Lappin-Scott HM. Binary and mixed population biofilms: time-lapse image analysis and disinfection with biocides. J Ind Microbiol Biotechnol 2002;29:331-338.

108. Bardouniotis E, Huddleston W, Ceri H, Olson ME. Characterization of biofilm growth and biocide susceptibility testing of Mycobacterium phlei using the MBEC assay system. FEMS Microbiol Lett $2001 ; 203: 263-267$. 